\title{
EU, US, and TURKEY in THE CAUCASUS: IS THERE A CLASH OF INTERESTS?
}

\section{Nadir Devlet ${ }^{\star}$}

\begin{abstract}
Although the man player in the Catcasus is still the Rustion fotateraton it is not jus neighbozing powers suck as lron and Turkey. but also the EU and the US that have started showing their interest in the ragion duning the last decate - nomely, after the atssolwhon of the 30 iet

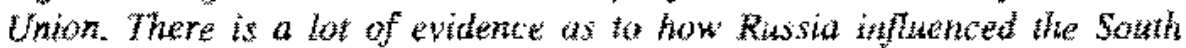

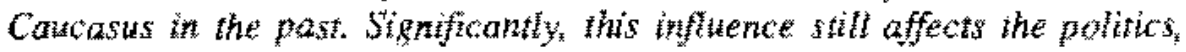
cconomies and social lafe of the region. A new player however began to infunce the regional situation in a number of important ways. Each party invalved in the region has ifs own interests, but the key interest tat every playe has could be summarized as a desife to get a larger share of the mion's energy resourses. It whild arterer that Turkey, being a NATO

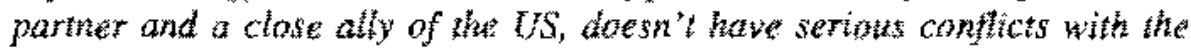
US in the Sowth Catadsus. America's more actwe twolvement in the region after September $1 \mathrm{~J}, 2000$, will force all parties to rewaminc thetr policies toward the region. It sems, however, that some of the EU projexts in the

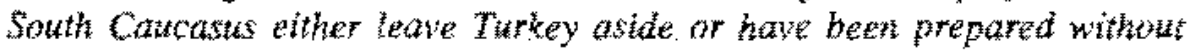
taking Turkey's inferests into consideration.
\end{abstract}

\section{Capacities of the United States Government in the Caucasus}

Us interests and policy foals in the Cancasus as wall as ne US governments overall dectson-maning stucture are affecting this region

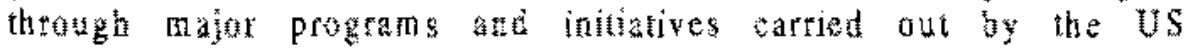
Department of sate (Dos). A gency for Intmentional Development

* Prof. Dr. Yeditepe University. 


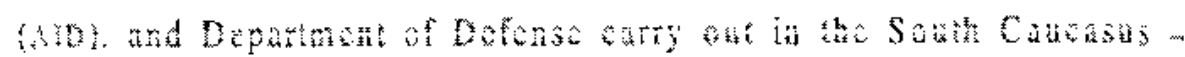
both in the rogion as a wole and in the thre countrias of Armenia, Azerbajan and Gevrgit. In the midde of 2002 , the US strategre influence in the Caucasus hat increased. Washington sent some military advisers to the region and lifted an arns ambrge imposed on Ammenia and Azelbaijan.

Sinco the Us government is comparatively large and because it pursucs the interests in virually every region of the wordd its activitigs in the South Caucavas are carried ant by a large number of adencics as well as by many non-govermmental orgatations that are funded by these agancres. The Us agencies that may afect contio prevention and

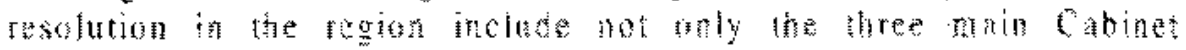
deparments of the Departrent of Sate, A tency for international De-

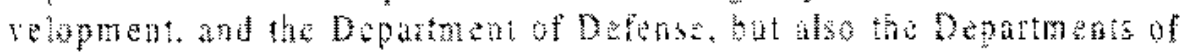

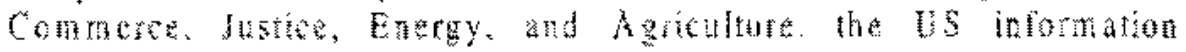
Agercy (Ista), and the independent federal agucies brown as the

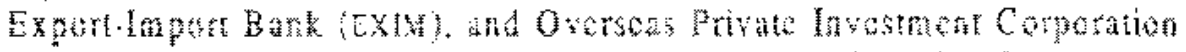
(opic) The US Corgress stould also he listed. sinee it often stapes sperific US palicies and debes on the butget resoures diected to the

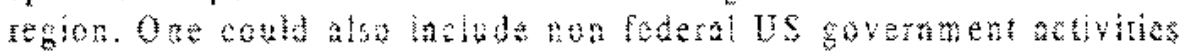
in the Caucusts, such as those of individual US states. Although they are ntet part of the US Goverment, the US Govemment is also a major influence on International fonandal and other inter-govennental orgatizations, such as the International Monetary Fund, the World Bank, and the lN Security Council, which arave a vitui impact on the region.'

Thus, the main interests of the US in the region now include incressing regional stablity and regional economic and poltical coopention preserving stable national political and economic tinates for investrent and diplonacy, maintaining at counterbalane in the region to the influence of Russia and Iran, promoting govemments that are friendly to the West and the US in purticuar, and gaining some acess to the reging on resoures. Hy and latge, the US has hat the closes relations with Coorgia ant incredsingly ood relations with

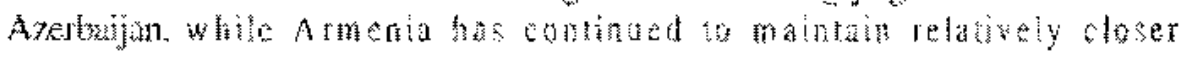
Itelations with Rustid.

There has been US participation in two roultinteral bodies in which it shates menbership with states in and around the region-the United vation and the OSCE: and 
military 4 to-mititary relations with some of the Caucasus countries in the region through bilateral programs and NATO."

The US goverment is one of the major providers of official development assistance to the Cancasts region. The US Agency for International Devolopment (USADt, piays an impotant role as special Coordinator for the disburament of aid.

It sas the Buth administration ${ }^{2}$ decision in fate February to send US military advisors to Georgla that seriously rattled the bulk of Rustia"s political class. Since then, the US and its NATO allies rapidy baye moved rapidy lo sireng thening their stategic foobold. 0 o $\mathrm{M}$ arch 21, a group of NATO experts atrived in Tbilis to inspect Vaziani military base, whoth Russiat troops evacuated anly last July and wheh

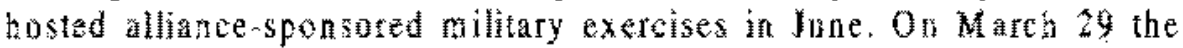
Us State Department announced the lifting of an arms embargo imposed an Armenia and Azerbutian.

\section{Armenia.}

The US Government is the largest provider of official development assistance 10 Armenia ( $\$ 2 \%$ of the total ir FY 1997 ). The total amount of US Gowenment assistance to Armenia from 1992-2001 is approximately $\$ 1.3$ billion. Other donors include the International Monetary Fund the findings of missions to examine monetary policy are incorporated into AID tachnical assistance); UN Conference on Trade and Developtnent (UNCTAD). the World Bank, the Europcan Union, the United Nations Children's Fund UNICEF), World Food Program, France, the Natherlands, Japan and Switzerland."

Other donors include the World Bank and the Arrentan Diasponats charitable contributions fiut orphatages, setools, health clinise ete, Contractors bave included UNiCen, Amencan International Health Allonec, Save the Cbilder Federation and the faternational Organization for Migration (10M).

\section{Azerbaijan}

In 1992. US atd to A zerbajan was severely restricted by Sextion 907 of the US Fredorn Support Act. whith prohithited aiding govemments 


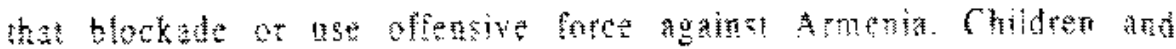

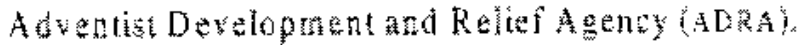

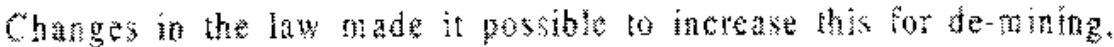

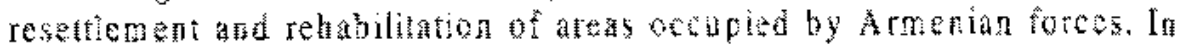

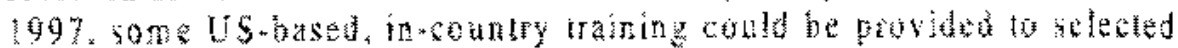

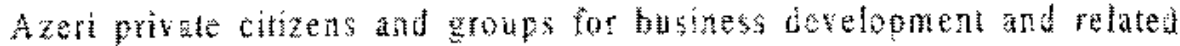

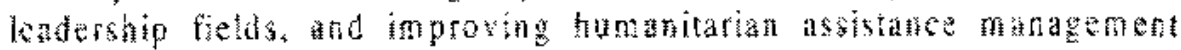

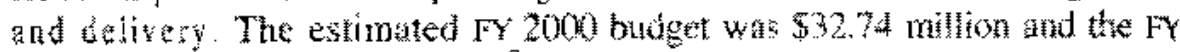
2001 request was $\$ 54.56$ million.

presiden George W. Busth cleared the way on April 19 for the US of

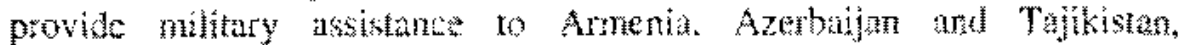
rewarding the govermments concemed for their copoptron in the war

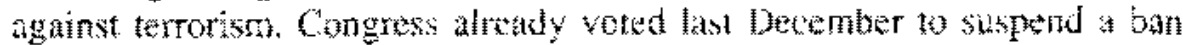
on US military ato to Amethatan."

\section{Geor}

In recent years, the orarall gats of usato prowams bave involved economic mestructuring, domocratic transiton, social stablization and

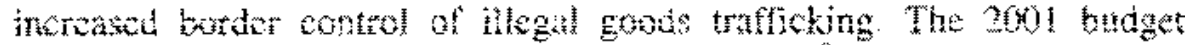

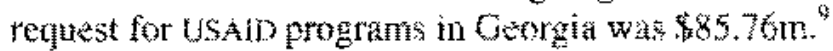

\section{Capacitice of the European Union in the Caucasus}

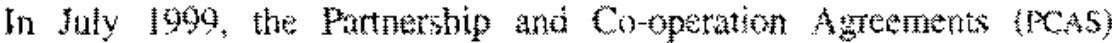

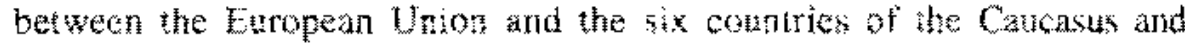

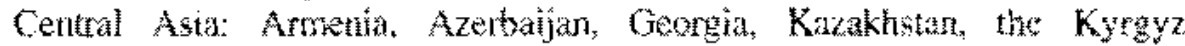

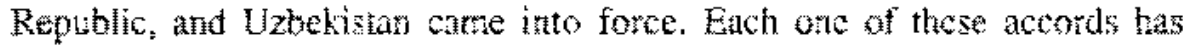
been established ton a perion of ten years, after which it will be tacity

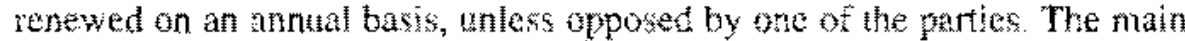

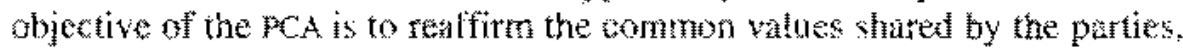
notably the principle of patianentary democricy pluatsm and the rule of las. It covers the protection of heman rights and the intrountion of a matket econgrmy.

The areas covered by these a

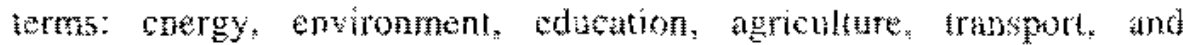

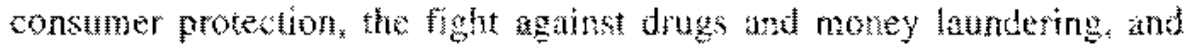
tourismo 
The first meeting of the Comoperation Council for Amenia. Georgia and Azerbajan was held on 12 Detober 1999 , and the second meeting on 10 October 2000 . It will be necessary to judge the effechiveness of this instrument with reference to the results achieved in the area of political dialogue and exchange.

The development programs of stuctural assistance could have a great impact on conflict prevention. For this reason, the European Comsunity has instituted a number of programs with the aim of helping these countries sttengthen their independence. The progrtm of Technical Assistance for the Commonwealth of Independent States (TACIS) is the main instrument which the Commission has at its disposal The TACls program consists of National Action Program' and a 'Regional Program'. Regional Programs form abou: $30 \%$ of the TACIS budget.

As regards the National Programs, priority sectors in the three South Caucasus countries concern: support for public and private sector enterprises, energy, human resources and administrative reforms. In the period of 1991-1997, about 85 of all all racts projects were well targeted at meeting the needs of the selected partners of beneficianies. In 1991-1997, a total of $\Theta 3.3$ billion ( 33 billion) was allocated to TACIS. In the same period, the South Caucasus countries received the following allocation: Amenis (049 million/\$44.6 million), Azerbatjan (65 million/ $\$ 46.6$ million) and Georgia ( $E 50$ million $\$ 45.5$ million), which puts them in the sixth, seventh and eighth place among the 30 beneficiary countries of TACIS. They are far behind Russia and Ukraine. In comparison, Armenia, Azerbaijan and Georgia reeived an equivalent of 1,5 of the budget each.

Under the new TACIS Regulation, the EU will allocate $\epsilon_{3.138}$ billion ( 22.856 billion the partner States in Eastem Europe and Central Asia over $2000+2006$.

Regional Brograms are not country *specific and exist alongside the national programs. Such programs include the Inter-Srate and CrossBorder Co-opention Program, as well as the Nackar Safty Prograta.

The Inter-5tate Program addresses problems that require similar solutions and aims fo establith working relation batween the salected countries. TRACECA and NOGATE are cumently the two main progrant. The TRACECa - Transport Corridot-Europe-Caucasas-A sia prograts -helps develop a trade comidor on an East-W est a is from Cental Asia, 


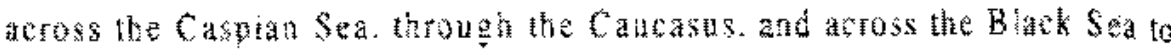

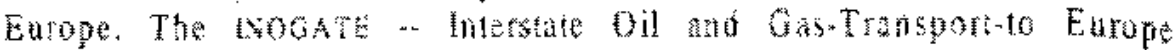

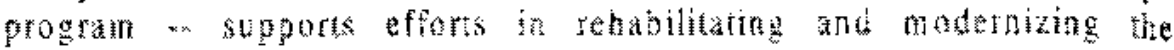

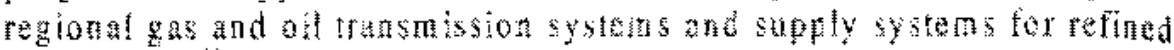
otitoridicts.

\section{Capacities of Turkey in the Caucasus}

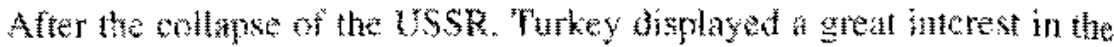

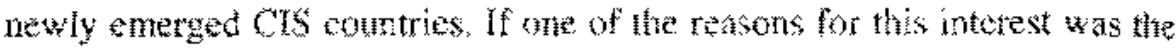

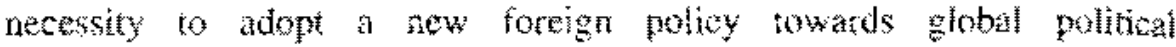

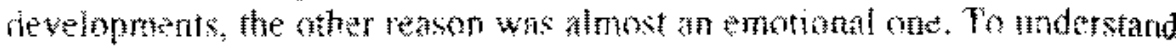

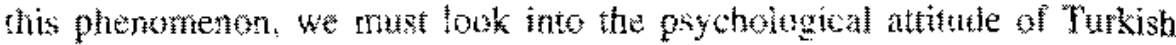

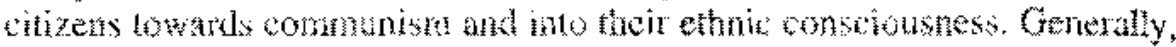

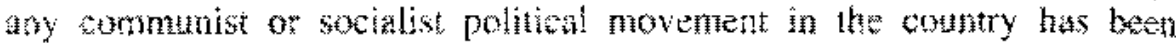

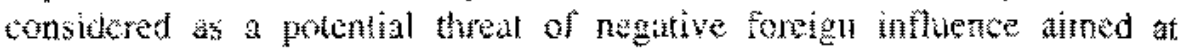

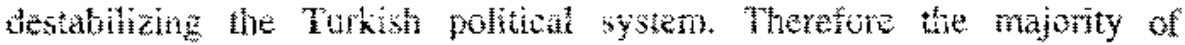

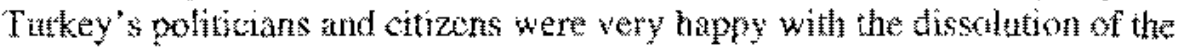
sovize Union and were in fawor of estabitibing retations with the ClS

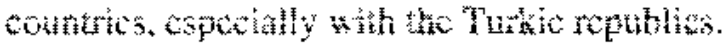

Non-Turkic peaples of Cancasan origin in Turkey are know untet the

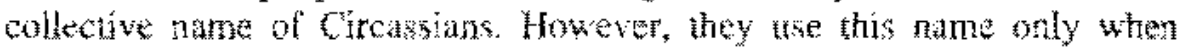

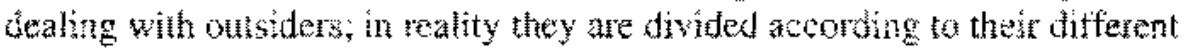

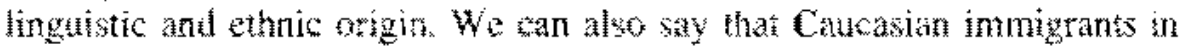
Thrkey share a sunse of common tistoricat unity. Snch sentiment also

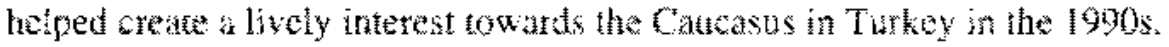

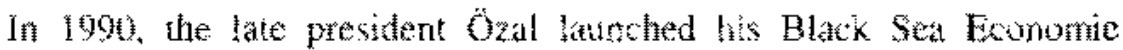
Cooperation zonc (BSECZ) initative, interded to eate trade barrous and

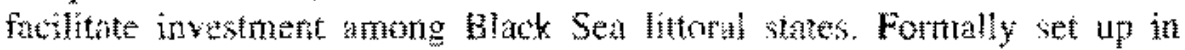

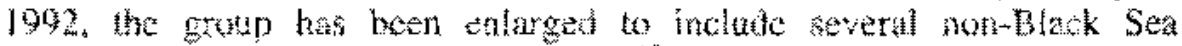

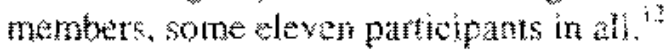




\section{Armenian-Turkish Relations}

While the economic and political ties with Azerbaijan and Georgia are getting stronger, Turkey and Amenia have not established formal diplomatic relations yet. The two countries are invalved in an array of disagreements that had worsened with the changes in Armenian government. The Turbish-Amenian border remains closed. This circumstance, however, has not been a political choice on the part of the Turkish government. The Amenian leadership was invited to pursue peaceful policies, which would certainly help increase the prosperity of its own people, as well as that of the region as a whole. This is the opinion of Ankara officials. The Nagorno-Karabagh crisis played a key role in the polarization in Armentan-Turkish relations.

Also, the genocide claims raised by the Amentan govermment and different Armenian groups in Diaspora, especially in France and the US, irtitate not just the Turkish government but the entire Turkish nation very much. Due to the pressure of Amenian lobbies, the legislative bodies of several countries and even the European Parliament have passed the laws that have recognized these claims. ${ }^{13}$

\section{Georgian-Turkish Relations:}

Now Azerbajan and Georgia consider each other strategic partiers. The economic cooperation and the construction of the oil pipeline from Baku to Supsa, a Georgian Black Sea port, encouraged these friendly attitudes, ${ }^{4}$

The Turkish Amed Forces logistics commander, Lieuterant-General Tursun Baki, and Ceorgia's Deputy Defense Minister, Major-General Grigol Katamadze signed in Tbilisi, on March 4,1999 , an agreement on military assistance and coperation between the two countries. 1 : One of those agrements provides for Turkish financial and technical aid to the Georgian armed forces over a five-year period. It will also include the training of Georgian military personnel in Turkey. The Turkish side recently allocated US55.5 million to develop the Georgian army's medical and rescue services. Last year, Turkey ptovided significant assistance to Geogian coastal guard. ${ }^{16}$ On January 28,2001 , Georgia's Speaker of Parliament Zurap Zhrania said that a former Soviet air base had been restored with the Turkish aid of $\$ 1,270,000$. Next day, Georgian Defense Minister David Tevzadze and his Turkish counterpart signed a cooperation agreement in Ankata on the military industry. On April 27, 2001, it was 
announed that the Republic of Turkey had gntanted $\$ 2,5$ hilion to Georatan military forces.

Gextgia kas a 1/4-kilemeter land botder with Turkey (the AzerbatjonTurkey torter is only $10 \mathrm{~km}$ long, and this border is important not only for miliaty but also for economic cocperation. Tuckey has alreaty reflaced Russio as Georgia's main trating partner."

\section{Azerbaljan-Twkish Relations}

Azerbainan and Turkey have deweloped very ibse relations following

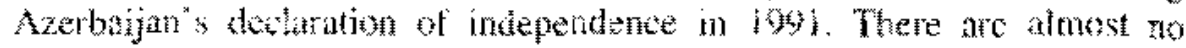
lingusistic batriers between the peoples of both countries. Tutkey

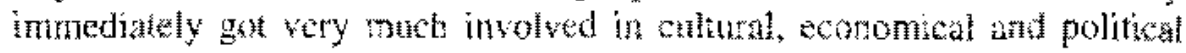
maters in Azerbaijan. We cart say that, of al the Turkic republios, the closest relations have been extablished with Azerbaijan. Turkey was and still is the ouly country that supports Azerbatian in the Karthagh conflict.

Russian thiltary inwolvement in the Cutusus and Moscow" s decision to back Yerevan in the Azerbatian. Amenian conflict forced Baku to look for tha ziew alles. Millary conperaton between Turkey and Azerbajan bas direaly started: some Azerbajint high ranking officers were trained or are still recening education at the Turkish Military Acadeny. Also, some Turkish oflices are working as advisers in Azebaijan. On September 20 , 2000, in Baku, Azorbajan's Defense Minister Safar Aliev and his Turkish counterpart Selahatin Cakmakughtu signed an agreement on cooperation in milifary industry. Growing Russian-Arnenian cooperation in the mitiary fleld is perceived as a threat to the regon's security by several countries including Turkey.

The proposed BakurCeyhan tain cxport pipeline from Azerbaijan to the Turkish Moditerranean pon of Ceyhun has been touted as the safest commercial and most politically viable rute by Turkey, the Unitted States, and the Caspian Sea oil proutucing countres, as they confirmed by the Ankara Decharation of October 1998. On Apri 29. 2002 , there was a surmit meting of Azerbajan. Gengia and Turkey. which death with the future of Baku-Ceylan pipeine profect. 


\section{Conclusion}

Since Turkey has not been accepted into the European Union, it has to search for new possibilities in order to solve its serious economical problems. Some highranking officers have hinted that Turkey should consider the possibilities of developing closer cooperation with neighboring countries such as the Russian Federation and even Iran. The dream of a "Comnon Turkish Market" is not realistic; the Turkic republics are also not exactly dreaming about it. Duting the initial stage of its relations with newly independent states, Turkey was dreaming about assuming the role of a "big brother ${ }^{3}$, but in due time it understood that it was not capable of performing such a challenging role. Therefor now Tukkey will be happy if it achieves some economical priorities, some financial gains.

But all these negative phenomena could not force Turkey to give up its interest in the Turkic peoples and in their destiny. As in the Cyprus caste, there might be a conflict between Turkey's and US interests in Eurasia. But in general, despite the fact that there are some forces in Turkey that are against such cooperation, the US and Turkey can reach accomnodation with the Russian Federation in the Caucasus.

The EU role in gentral - or, for that matter, the role of some member countries like Gemany or Great Britain - in the Caueasus is still not clear. Also, the prospective membership of Turkey in the EU $-m$ a controversial issue among Turkish politicians and intellectuals - is likely to become a reality only after a decate or so. Therefore, whether Turkey is going to cooperate on the Caucasus with the EU is still a big question, because there are many contradicting issues between Ankara and Brussels -- like Armerian genocide claims, to name just one. In short, today Turkey appears to be leaning in its Caucasus policies more on the US rather than on the EU.

\section{Endnotes}

Michael Land, "The Conflact Prevention Capacities of the Unifed States Government in the Caucasus" EWHFEWER SurWy $(2001) 41-62$.

${ }^{2}$ Optizip. 47.

${ }^{3}$ op.cit. p. 49 . 


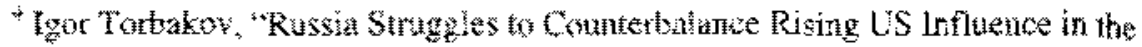

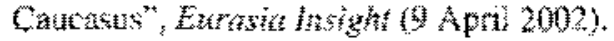

"Mituas Lund, "The Conthet Prevention Capacities of the Linitel States

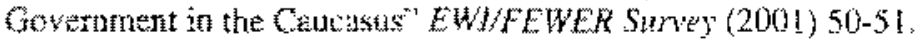

Op.cis.p. 54

Op. cit. p. 55 .

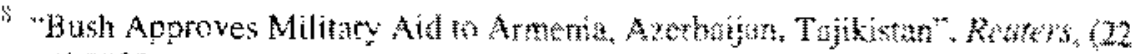
April 2002).

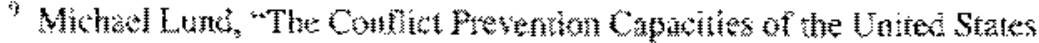

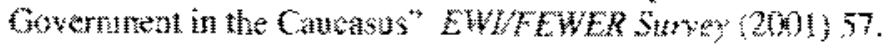

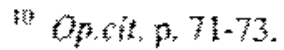

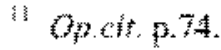

"Makoyky, A., "The New Activism in Turkigh Fotetge Policy", SAS Revizw (Winter-Spring 1999).

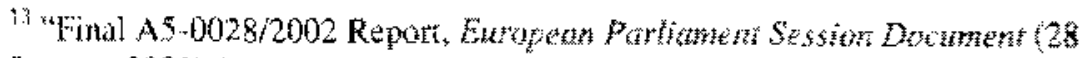
January 2002 ) $1-19$.

1. thed

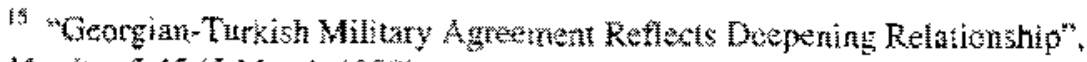
Antmatar 5,45 (5 March 199g)

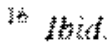

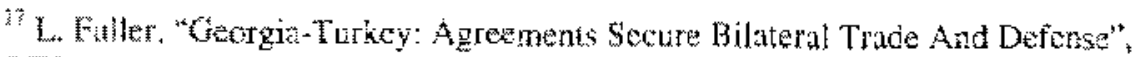

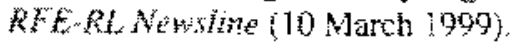

